\title{
Instructors' message variables and students' learning orientation/ grade orientation and affective learning
}

Leeanne M. Bell

West Virginia University

Follow this and additional works at: https://researchrepository.wvu.edu/etd

\section{Recommended Citation}

Bell, Leeanne M., "Instructors' message variables and students' learning orientation/grade orientation and affective learning" (2003). Graduate Theses, Dissertations, and Problem Reports. 742.

https://researchrepository.wvu.edu/etd/742

This Thesis is protected by copyright and/or related rights. It has been brought to you by the The Research Repository @ WVU with permission from the rights-holder(s). You are free to use this Thesis in any way that is permitted by the copyright and related rights legislation that applies to your use. For other uses you must obtain permission from the rights-holder(s) directly, unless additional rights are indicated by a Creative Commons license in the record and/ or on the work itself. This Thesis has been accepted for inclusion in WVU Graduate Theses, Dissertations, and Problem Reports collection by an authorized administrator of The Research Repository @ WVU. For more information, please contact researchrepository@mail.wvu.edu. 
Instructors' Message Variables and Students' Learning Orientation/Grade Orientation and Affective Learning

Leeanne M. Bell

Thesis submitted to the College of Arts and Sciences at West Virginia University in partial fulfillment of the requirements for the degree of

\author{
Master of Arts \\ in \\ Communication Studies
}

Scott A. Myers, Ph.D., Chair

Melanie Booth-Butterfield, Ph.D.

James C. McCroskey, Ed.D.

Department of Communication Studies

Morgantown, West Virginia

2003

Keywords: Self- Disclosure, Humor, Narrative, Learning/Grade Orientation, Affective Learning 


\begin{abstract}
Instructors' Message Variables and Students’ Learning Orientation/Grade Orientation and Affective Learning
\end{abstract}

Leeanne M. Bell

The purpose of this study was to examine the relationship among instructors' message variables and students' learning orientation (LO), grade orientation (GO), and affective learning. Participants were 193 students (109 men, 83 women) enrolled in introductory communication courses at a large eastern university. Participants completed the Revised Self-Disclosure scale (Wheeless, 1978), the Humor Orientation scale (Booth-Butterfield \& Booth-Butterfield, 1991), a narrative scale created for this study, the LOGO II scale (Milton, Pollio, \& Eison, 1986) and the Instructional Affect Assessment Instrument (IAAI) (McCroskey, 1994). Results indicated instructors' message variables were not significantly related to students' LO/GO, no significant differences among the four categories of LO/GO, and when controlling for LO/GO, few significant relationships were obtained between instructors' message variables and affective learning. Future research should examine if instructors' own learning orientation or grade orientation influences how LO/GO students perform in their course. 
Acknowledgements

The following individuals' encouragement, support, and guidance have made this thesis possible. Scott- Thank you very much for taking the time out of your busy schedule to always proof read my work and make sure that everything was perfect. I greatly appreciate your help. You are a wonderful instructor despite the red pen!

Melanie and Jim- Thank you for your insight and ideas I greatly appreciate all of the time that you spent reading my work and giving me your ideas and opinions.

Corey- Without your love I would have never made it through this program. You pushed me to do my best and never gave up on me. I know this year was not fun for you either but you never complained and always came to visit. Thank you for being there for me. I love you!

My family- Thank you for always being there to wipe away my tears. Your support and encouragement helped me get through this program. Thank you for having faith in me. I have learned to always work hard and dedicate myself to my work through watching you. You have made me the person I am today. I love you all.

Alicia (my six-footer friend)- We never thought we were going to get through this but we did and I am glad that we did it together. Thank you for always being there for me. I will never forget our long walks to procrastinate work, our cookie fudge fantasies after the hard work, and our dilemmas and drama that always seemed to occur when we were together. "Yesterday brought the beginning, tomorrow brings the end, but in the middle we have become the best of friends." The Master's Class- Congratulations, we made it through this program! We all stuck together through the rough times and all became stronger for it. I am sure that you will all succeed in whatever you put your mind to. I will always remember each of you. Take care, keep in touch, and always keep in mind that anything worth having isn't easy to get. 
I. REVIEW OF LITERATURE................................................................

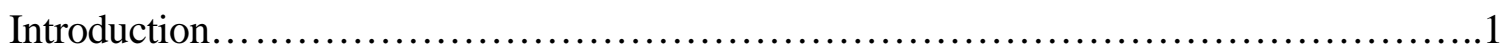

Self-Disclosure, Humor, Narratives …..........................................

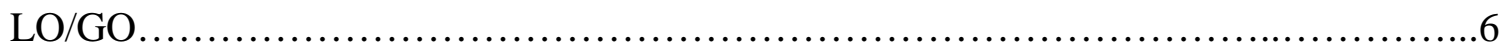

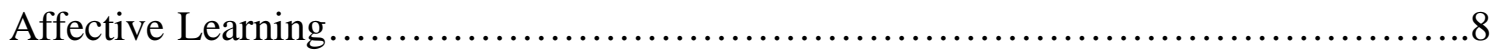

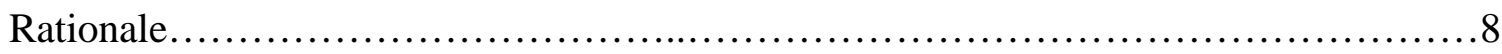

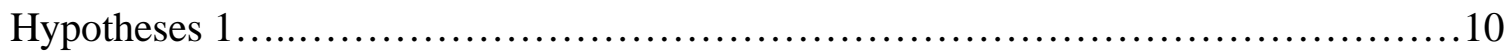

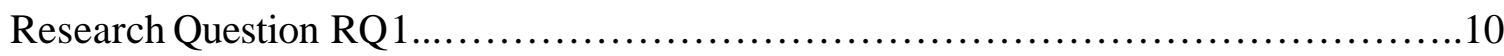

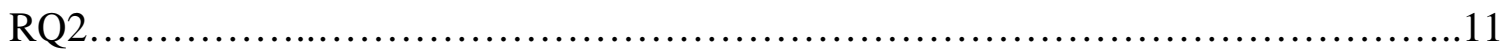

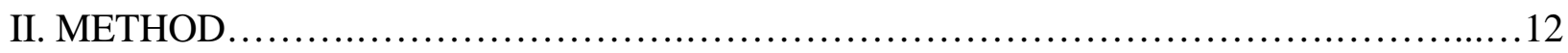

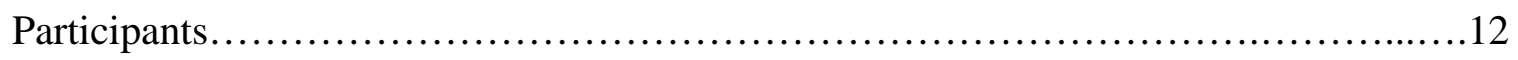

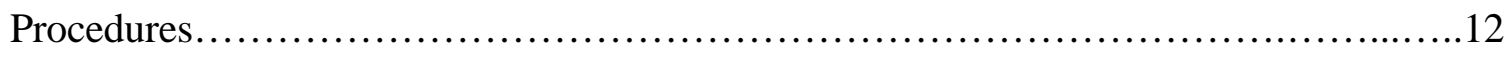

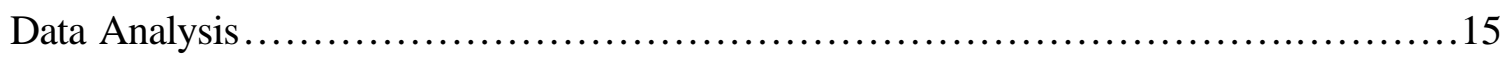

III RESULTS

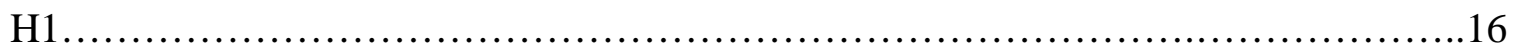

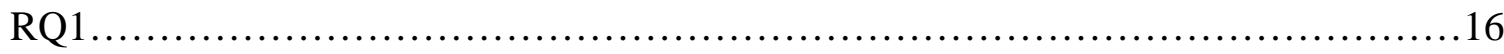

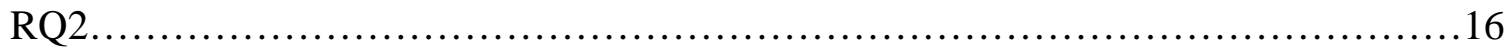

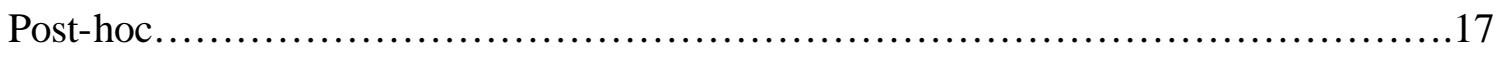

\section{DISCUSSION}

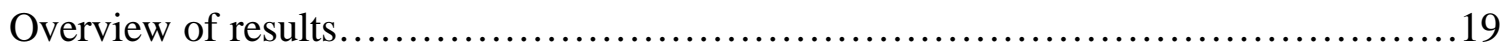

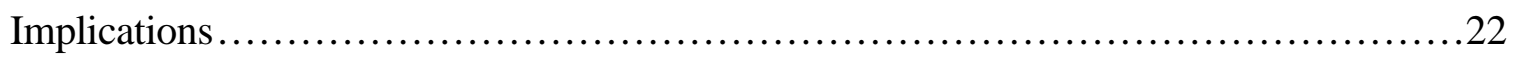




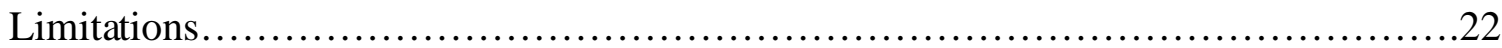

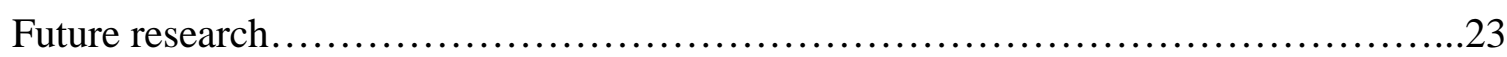

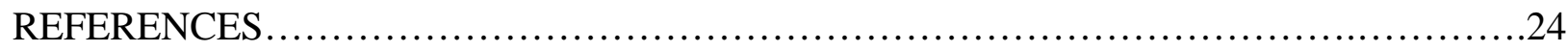

APPENDIXES

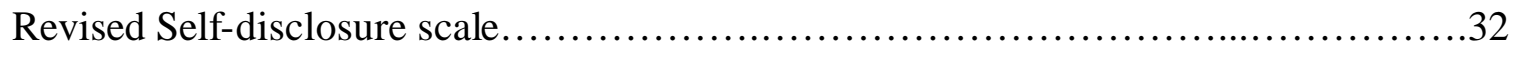

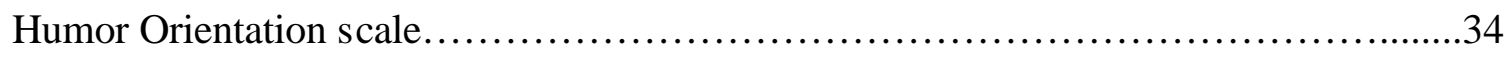

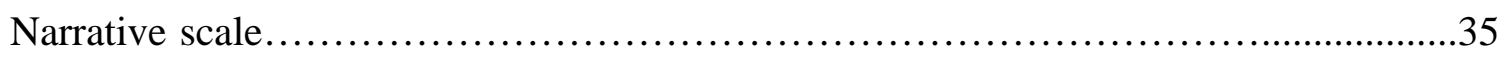

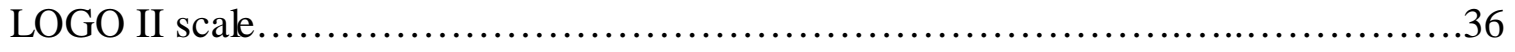

Instructional Affect Assessment instrument ...........................................37

\section{TABLES}

Scales, Means, Standard Deviations, and Reliabilities................................38

Correlation Matrix Among All Variables ..........................................39

Pearson-Product Moment Correlations between Instructors' Message Variables and

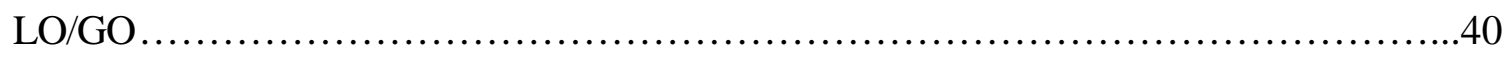

Differences in Mean Scores Among LO/GO........................................41

Partial Correlations between Instructors' Message Variables and Affective Learning

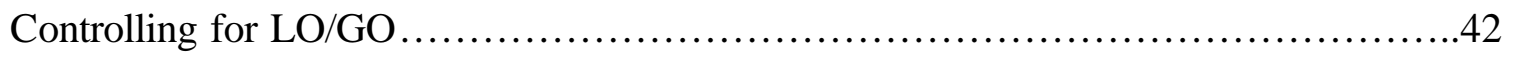




\section{CHAPTER 1}

Introduction

This study examined the relationship among instructors' message variables (i.e., selfdisclosure, humor, narrative), students' learning orientation (LO) and grade orientation (GO), and students' affective learning. Because instructors' communication behaviors can have a positive effect on students (Downs, Javidi, \& Nussbaum, 1988), it is possible instructors' message variables may also affect students' LO and GO. In this study, instructor self-disclosure, humor, and narrative are three communication behaviors that comprise the construct known as instructors' message variables. When instructors use these variables appropriately, this use has an important impact on students. Students view their college education in many different ways; therefore instructors' behaviors will have more or less of an impact depending on the student. Moreover, students' affective learning may also be influenced by their LO and GO. The first section of the literature review focuses on instructors' use of self-disclosure, humor, and narrative. The second section of the literature review focuses on students' perceptions of their education, which is separated into their LO and GO. The third section of the literature review focuses on students' affective learning. Self-Disclosure, Humor, and Narrative

The first variable to be examined is self-disclosure. Self-disclosure is defined as any unknown information (Pearce \& Sharp, 1973) individuals communicate verbally about themselves to other individuals (Cozby, 1973). Self-disclosure has three dimensions, which are breadth (Altman \& Taylor, 1973), depth (Altman \& Taylor, 1973), and duration (Cozby, 1973). Breadth is defined as the amount of information disclosed, depth is defined as the intimacy of information disclosed, and duration is defined as the time spent by an individual describing each 
item of information (Cozby, 1973). In the communication field, Wheeless and Grotz (1976) conceptualized self-disclosure as consisting of five dimensions. These dimensions are amount, intent, honesty, valence, and depth. Amount is defined as the frequency and the duration of the disclosure, intent is defined as the willingness of the individual to disclose, honesty is defined as the truth of those revelations, valence is defined as positive and/or negative statements revealed by the individual, and depth is defined as the self-perceived intimacy of the information-topic revealed (Wheeless \& Grotz, 1976).

Regardless of how self-disclosure is conceptualized, five generalizations about selfdisclosure exist in the interpersonal communication research (Pearce \& Sharp, 1973). First, relatively few communication transactions involve high levels of disclosure, although individuals are always self-disclosing information (Altman \& Taylor, 1973). Second, self-disclosure usually occurs in dyads. Third, self-disclosure is usually symmetrical. Fourth, self-disclosure occurs in the context of a positive relationship. For example, individuals who use more self-disclosure are perceived as likable (Collins \& Miller, 1994), and trustworthy (Wheeless, 1978; Wheeless \& Grotz, 1977). Fifth, self-disclosure usually occurs incrementally.

Self-disclosure is viewed as central to the development of close interpersonal relationships (Altman \& Taylor, 1973). Individuals who engage in intimate disclosures tend to be liked more than individuals who disclose at lower levels (Collins \& Miller, 1994). Moreover, individuals disclose more to those individuals they like (Collins \& Miller, 1994). Personal and negative disclosures occur later in relations hips whereas positive disclosures occur earlier in relationships (Gilbert \& Whiteneck, 1976). Women and same-sex relational partners disclose more often than men and opposite-sex relational partners (Dindia \& Allen, 1992).

Self-disclosure is also central to the development of the instructor-student relationship. In 
the instructional setting, self-disclosure is used by instructors to clarify course content (Downs et al., 1988; Nussbaum, Comadena, \& Holladay, 1985) and to motivate students (Sorensen, 1989). Generally, instructors self-disclose about their education, their teaching experience, their family and friends, their beliefs and opinion, their leisure activities, and their personal problems (Downs et al., 1988; Holladay, 1988; Nussbaum et al., 1985). College instructors' self-disclosure is related positively to the instructor's experience (i.e., how long they have been teaching) (Javidi \& Long, 1989) and award winning instructors tend to use more self-disclosure in the classroom than nonaward winning instructors (Downs et al., 1988). Self-disclosure also has a positive impact on student participation (Goldstein \& Benassi, 1994).

Students may perceive their instructors' self-disclosures as intentional or unintentional, entertaining or self-indulgent, risky or safe, and relevant or irrelevant to course topics (Nussbaum \& Scott, 1979). Nussbaum and Scott (1979) found that perceived honesty of instructors' self-disclosures positively contributed to students' perceived affective and behavioral learning, but were negatively associated with students' perceived cognitive learning. Selfdisclosure in the classroom leads to students' perceived solidarity with the ir instructors (Sorensen, 1989). Perceived honesty in self-disclosure is positively related to a students' evaluation of an instructor's overall performance (Sallinen-Kuparinen, 1992; Scott \& Nussbaum, 1981). Additionally, instructors who self-disclose in the classroom are perceived as being more assertive (Cayanus \& Martin, 2002), more responsive (Cayanus \& Martin, 2002), more nonverbally and verbally immediate (Sorensen, 1989), and more effective (Nussbaum et al., 1985).

The second variable to be examined is humor. Humor is a complicated social psychological communication event (Civikly, 1986) that is culturally influenced and 
temperamentally based (Wrench \& McCroskey, 2001). Humor enactment is viewed as an intentional verbal and/or nonverbal message that provokes laughter, delight, and/or surprise to a receiver (Booth-Butterfield \& Booth-Butterfield, 1991; Graham, Papa, \& Brooks, 1992). Research has shown that humor, in most cases, has a positive impact on individuals' lives. Humor has been positively associated with high levels of self-esteem (Kuiper \& Martin, 1993), high levels of empathic concern (Hampes, 2001), and high levels of attractiveness (Murstein \& Brust, 1985). Humor can provide comfort (Bethea, 2001; Bippus, 2000), reduce anxiety (Yovetich, Dale, \& Hudak, 1990), reduce stress (Martin \& Lefcout, 1983), lower uncertainty (Graham, 1995), and build emotional exp ressivity (Wanzer, Booth-Butterfield, \& Booth Butterfield, 1997). Moreover, humor makes hurt-evoking messages appear less intentional and less hurtful (Young \& Bippus, 2001).

Not only has humor been studied in numerous contexts (Murstein \& Brust, 1985; Rizzo, Booth-Butterfield, \& Wanzer, 1999; Wanzer, Booth-Butterfield, \& Booth-Butterfield, 1995; Wanzer \& Frymier, 1999), but it also has been operationalized in numerous ways. One way in which humor has been operationalized is through a concept known as humor orientation (BoothButterfield \& Booth-Butterfield, 1991). Humor orientation (HO) is conceptualized as the way in which individuals regularly enact humor in interactions (Booth-Butterfield \& Booth-Butterfield, 1991). Individuals are considered to be high, moderate, or low in HO. High HO individuals regularly use humor in most of their behaviors, perceive more situations as appropriate for using humor, view fewer situations as inappropriate for humor attempts, and make use of many different categories of humorous communication (Booth-Butterfield \& Booth-Butterfield, 1991). Low HO individuals, on the other hand, view fewer situations as appropriate to use humor (Booth-Butterfield \& Booth-Butterfield, 1991). 
In the interpersonal communication domain, the study of $\mathrm{HO}$ has garnered much attention. $\mathrm{HO}$ has been positively correlated with the communication traits of communicator adaptability, concern for eliciting positive impressions, affective orientation, and situational sense of humor (Wanzer et al., 1995). High HO has been associated with lower levels of loneliness, greater levels of attraction, and greater ease with making friends (Wanzer, BoothButterfield, \& Booth-Butterfield, 1996). High HO individuals are positively related to perceived attractiveness (Murstein \& Brust, 1985; Wanzer et al., 1996), creativity (Hauck \& Thomas, 1972), and communication flexibility (Wanzer et al., 1996). In the workplace, high HO employees are more likely to use humorous behaviors and high HO managers are perceived to be more effective and likable (Rizzo et al., 1999). Employees' perceptions of managers' being high $\mathrm{HO}$ are positively correlated with satisfaction with their managers, perceived managers' responsiveness, and perceived managers' approach strategies, but are negatively correlated with managers' use of avoidance strategies (Campbell, Martin, \& Wanzer, 2001).

In the instructional setting, humor is also important (Bryant, Comisky, \& Zillmann, 1979; Downs et al., 1988). Humor can consist of jokes, riddles, puns, funny stories, and funny comments (Bryant et al., 1979). Regardless of the type of humor used, experienced instructors tend to use more humor than less experienced instructors (Javidi \& Long, 1989), award-winning instructors use less humor than non-award winning instructors (Downs et al., 1988), and high school instructors use less humor than college instructors (Neuliep, 1991).

Humor in the classroom has focused both on the instructor (Bryant et al., 1979; Downs et al., 1988; Javidi \& Long, 1989; Neuliep, 1991) and the impact on students (Gorham \& Christophel, 1990; Wanzer \& Frymier, 1999). Instructors' use of humor is used to gain students' compliance (Punyanunt, 2000), help students retain information (Kaplan \& Pascoe, 1977), 
clarify course content (Downs et al., 1988), and increase students' learning (Gorham \& Christophel, 1990; Hauck \& Thomas, 1972). Humor can also create an enjoyable learning environment (Neuliep, 1991) and instructors who use humor are perceived by students to establish a supportive classroom climate (Darling \& Civikly, 1987; Stuart \& Rosenfeld, 1994).

The third variable to be examined is narrative. Narrative activity is defined as the "process of story-telling" (Holladay, 1987, p. 2) and is an effective dramatic device used in the classroom (Holladay, 1987). For a narratives to be successful, it must be told effectively. Not only are effective instructors perceived to know how to tell a good story (Norton \& Nussbaum, 1980), but effective instructors frequently tell "better" narratives than "bad" narratives (Holladay, 1987). Through use of narrative, instructors implicitly encourage students to participate in the learning process (Kirkwood \& Gold, 1983). When instructors use narrative, they motivate students to take information from class and apply it to the "real" world (Kirkwood \& Gold, 1983), enhance student recall (Holladay, 1987), clarify course content (Downs et al., 1988; Eble, 1976; Javidi \& Long, 1989), provide examples that students understand (Eble, 1976), increase student participation in class and class discussion (Kirkland \& Gold, 1983), and create a positive relationship with students (Eble, 1976; Holladay, 1987).

These three aforementioned behaviors are centered on students' perceptions of their instructors' message variables. Although the primary intent behind instructors' use of selfdisclosure, humor, and narrative is to clarify course content (Downs et al., 1988), these three behaviors also act as important influences on student outcomes. The next section of the literature review focuses on students' perceptions of their education, specifically their learning orientation and their grade orientation.

\section{Learning Orientation/Grade Orientation}


Students view their educational experience in many ways. Two ways in which students view the ir education are through their learning experiences and their attempts to obtain the best grades. These two views are known as learning orientation (LO) and grade orientation (GO). LO is defined as "students view[ing] the college classroom as a context in which they expect to encounter new information and ideas that will be both personally and professionally significant" (Milton, Pollio, \& Eison, 1986, p. 126) whereas GO is defined as “students view[ing] the college experience as a crucible in which they are tested and graded and which is endured as a necessary evil on the way to getting a degree or becoming certified in a profession" (Milton et al., 1986, p. 126). LO and GO can be further separated into attitudes and behaviors. Attitudes are defined as a student's expression or desire to acquire knowledge or grades whereas behaviors are defined as the action a student takes to achieve learning or a grade (Milton et al., 1986). Richardson, Kring, and Davis (1997) found that the students' perceptions of what is important in education does not translate into the actual behaviors that are being performed; hence, a discrepancy between attitudes and behaviors may exist.

Learning and grade orientation simultaneously contribute to students' perceptions of their instructors, themselves, and the ways in which they interact with their instructors (Pollio \& Beck, 2000). LO students are more emotionally stable, trusting, imaginative, forthright, placid, selfsufficient, and relaxed than GO students (Milton et al., 1986). At the same time, LO students are more dogmatic than GO students (Beck, Rorrer-Woody, \& Pierce, 1991), although GO students believe manipulative tactics are appropriate to use when obtaining grades (Beck et al., 1991). Beck et al. (1991) found relatively low levels of academic ability contributed to the poor grades of high GO students. Students with lesser academic skills are under more pressure to obtain better grades, therefore making them more GO (Johnson \& Beck, 1988). High LO students 
choose a college based on its curriculum whereas high GO students are more concerned with their success at college (Alexitch \& Page, 2001). But regardless of their orientation, students report greater learning in a highly student-centered classroom (Lawrence \& Frymier, 2002).

Both LO and GO students prefer to have instructors who are LO; however, most instructors are GO (Pollio \& Beck, 2000). Instructors reported they would rather be LO, but they believe that a strict focus on grades leads students to perceive them as GO. Instructors who reported being high GO professors direct their classes towards challenging the most intelligent students to compete for their grades (Pollio \& Beck, 2002).

\section{Affective Learning}

The next variable to be examined is affective learning. Students' perceived affective learning plays an important role in the classroom. Affective learning is defined as the positive attitudes, beliefs, and values students attach to the instructor's communication in the classroom and consists of affect toward the course instructor, affect toward the course content, and affect toward the recommended course behaviors (McCroskey, 1994). Affective learning has been positively correlated with several perceived instructor communication behaviors, which include self-disclosure (Sorensen, 1989), humor (Gorham \& Christophel, 1990; Wanzer \& Frymier, 1999), verbal immediacy (Gorham, 1988; Sanders \& Wiseman, 1990; Witt \& Wheeless, 2001), verbal receptivity (Robinson, 1993), nonverbal immediacy (Plax, Kearney, McCroskey, \& Richmond, 1986; Sanders \& Wiseman, 1990; Witt \& Wheeless, 2001), affinity seeking (Dolin, 1995; Frymier, 1994), clarity (Sidelinger \& McCroskey, 1997), and expression of caring (Teven \& McCroskey, 1997). A negative correlation exists between affective learning and instructor use of antisocial behavior alteration techniques (Plax et al., 1986).

Rationale 
The purpose of this study is to examine the relationship among perceived instructors' use of self-disclosure, humor, and narrative, students' LO and GO, and students' affective learning. Although instructors can use self-disclosure, humor, and narrative to assist in students' learning, how students perceive their own learning experiences determines whether instructors' use of these behaviors is effective. The first three behaviors that are examined focus on instructors' message variables. Previous research has demonstrated that these three message variables all benefit students' performance in class. Self-disclosure, humor, and narrative are all ways in which instructors can positively affect student learning (Eble, 1976; Gorham \& Christophel, 1990; Nussbaum \& Scott, 1979). These three message variables also are associated positively with effective instruction(Holladay, 1987; Javidi \& Long, 1989; Nussbaum et al., 1985). At the same time, self-disclosure, humor, and narrative make course content more interesting for students (Downs et al., 1988; Nussbaum et al., 1985). As such, LO students should enjoy classes in which instructors use self-disclosure, humor, and narrative because LO students are interested in intellectual matters, are considered to be free and creative, and find learning new material “fun” (Eison \& Pollio, 1985). Moreover, LO students seek more academic help from their instructors (Alexitch, 1997), develop stronger relationships with their instructors (Alexitch, 1997), and consider the ideal professor to be an individual who strives to produce student interest while appreciating student input (Pollio \& Beck, 2000).

Conversely, GO students view instructors who strive to produce interesting material that is not related to course material as disorganized (Pollio \& Beck, 2000). When instructors selfdisclose about family, teaching experiences, or their leisure (Holladay, 1988), it is possible GO students will not be pleased. GO students prefer highly structured courses that are controlled by prepared instructors (Pollio \& Beck, 2000). GO students are more likely to withdraw from an 
interesting course (Milton et al., 1986), get irritated when other students ask questions (Milton et al., 1986), and inquire what will be on tests (Pollio \& Beck, 2000). Moreover, GO students believe that without regularly scheduled exams, they would not learn or remember class content (Milton et al., 1986). Thus, GO students may not enjoy instructors who self-disclose, use humor, and tell narratives in class. To investigate this idea, the following hypothesis is proposed:

H1: Perceived instructors' self-disclosure (i.e., amount, valence, depth), humor orientation, and narrative will be positively correlated with students' LO, but negatively correlated with students' GO.

Traditionally, researchers have only examined the differences between LO and GO students (Alexitch, 1997; Alexitch \& Page, 2001; Eison \& Polio, 1985; Kauffmann, Chupp, Hershberger, Martin, \& Eastman, 1987; Richardson et al., 1997), but students may not fit perfectly into one of these two categories (Miton et al., 1986). It is possible for students to be both learning and grade oriented (Milton et al., 1986). Milton et al. (1986) proposed four categories of LO and GO: high LO/high GO, high LO/low GO, low LO/high GO, and low LO/low GO. High LO/high GO students are motivated to learn while striving to achieve high grades. High LO/low GO students are concerned with the learning aspect of education and view grades as irrelevant. Low LO/high GO students focus on the grade they will achieve in the classroom and grade achievement often becomes more important than learning. Low LO/low GO students do not care about either learning or grades and are likely attending college for alternative reasons such as socializing or getting away from home (Milton et al., 1986). Thus the following research question is posed:

RQ1: How do students who vary in their LO/GO orientations differ in their assessment of instructors' self-disclosure (i.e., amount, valence, depth), humor orientation, and 
narrative?

Self-disclosure, humor, and narrative are used in the classroom as ways to help the students understand the information being taught (Downs et al., 1988). By using these three behaviors, students who either are LO or GO may find the information as being more relevant to their life and perceive it as important and interesting. Self-disclosure (Sorensen, 1989) and humor (Gorham \& Christophel, 1990; Wanzer \& Frymier, 1999) have been positively correlated with perceived affective learning. Developing favorable or unfavorable attitudes toward learning may be influenced by students' LO/GO and how they perceive their instructors who use these message variables. LO and GO students may have different goals for the classroom, but it is unclear whether students' LO and GO influences their affect for the course and affect for the instructor when the instructor is perceived as using self-disclosure, humor, and narrative. Thus, the following research question is posed:

RQ2: How does students' LO/GO affect the relationship among perceived instructors' self-disclosure (i.e., amount, valence, depth), humor orientation, and narrative and students' affective learning? 


\section{CHAPTER 2}

Method

\section{Participants}

Participants were 193 students enrolled in introductory communication courses at a large eastern university. Participants included 109 men and 83 women. The age of the respondents ranged from 18 to 53 years $(M=21.4, S D=3.49)$. Two participants were first year students, 40 participants were sophomores, 80 participants were juniors, 62 participants were seniors, and eight participants were "other."

\section{Procedures and Instruments}

Participants voluntarily completed five instruments. These instruments were the Revised Self-Disclosure scale (Wheeless, 1978), the Humor Orientation scale (Booth-Butterfield \& Booth-Butterfield, 1991), a narrative scale created for this study, the LOGO II scale (Milton et al., 1986) and the Instructional Affect Assessment Instrument (IAAI)(McCroskey, 1994). For the first three scales, participants were asked to recall a previous instructor and to complete the instrument s in reference to the instructor. For the LOGO II and the IAAI scales, participants reported on their own perceptions of their education. Table 1 presents the mean, standard deviation, and reliabilities of all the scales.

The Revised Self-Disclosure scale (Wheeless, 1978) is a 31-item instrument that asks respondents to report their perceptions of the amount, intent, honesty, valence, and depth of their self-disclosure (see Appendix A). In this study, the scale was modified in that participants were asked to rate their instructor's perceived self-disclosure on a 7-point Likert-type scale ranging from strongly agree (7) to strongly disagree (1). Even though all 5 dimensions were used on the scale, this study will focus on the dimensions of amount of self-disclosure, valance of self- 
disclosure, and depth of self-disclosure. Intent of self-disclosure and honesty of self-disclosure will be disregarded, because students might have difficulty determining instructors' intent and honesty to self-disclose. Previous reliability coefficients ranging from .75 to .89 (Bograd \& Spilka, 1996; Stack \& Stone, 1984; Wheeless, 1978; Wheeless, Nesser, \& McCroskey, 1986) have been reported for the subscales. In this study, subscale scores were: amount $(M=28.10, S D$ $=7.75$, alpha $=.79)$, intent $(M=20.13, S D=4.33$, alpha $=.76)$, honesty $(M=38.95, S D=7.24$, alpha $=.81)$, valence $(M=35.31, S D=6.46$, alpha $=.77)$, and depth $(M=16.75, S D=5.79$, alpha $=.73)$.

The Humor Orientation scale (Booth-Butterfield \& Booth-Butterfield, 1991) is a 17-item instrument that assesses how likely an individual is to produce humorous messages such as funny stories and jokes (see Appendix B). In this study, participants were asked to rate their instructor's perceived $\mathrm{HO}$ using a five-point Likert-scale ranging from strongly agree (5) to strongly disagree (1). Previous reliability coefficients ranging from .82 to .93 have been reported for the scale (Campbell et al., 2001; Rizzo et al., 1999). In this study, a reliability coefficient alpha of $.95(M=62.18, S D=15.2)$ was obtained for the scale.

The Narrative Scale is a 10-item scale that was designed specifically for this study (see Appendix C). Items were generated based on studies by Nussbaum, et al. (1985) and Holladay (1987). Participants were asked to rate their instructor's use of narrative using a five-point Likert-scale ranging from strongly agree (5) to strongly disagree (1). A pilot test, conducted on 111 undergraduate students, revealed a reliability coefficient alpha of $.75(M=33.23, S D=$ 6.57). In this study, a reliability coefficient alpha of $.80(M=34.50, S D=7.09)$ was obtained for the scale.

The LOGO II scale (Milton et al., 1986) is a 32-item instrument that assesses how 
students perceive their education (see Appendix D). The first 16 items assess students' attitudes toward learning and the second 16 items assess students' behaviors toward learning. In this study, only the 16 items measuring attitudes were used. Eight items reflect LO and eight items reflect GO. Participants were asked to rate themselves using a five-point Likert-scale ranging from strongly agree (5) to strongly disagree (1). Previous reliability coefficients ranging from .70 to .77 have been reported for the LO scale and reliability coefficients ranging from .72 to .81 have been reported for the GO scale (Alexitch, 1997; Frymier \& Weser, 2001; Lawrence \& Frymier, 2002). In this study, a reliability coefficient of $.66(M=27.38, S D=4.62)$ was obtained for the LO scale and a reliability coefficient of .60 $(M=28.36, S D=4.69)$ was obtained for the GO scale.

The Instructional Affect Assessment Instrument (IAAI) (McCroskey, 1994) is a 24- item instrument that measures student affect across six subscales (see Appendix E). In this study, four of the six subscales were used to measure student affective learning. Affect toward the instructor was measured by two, four-point subscales that asked about the student's attitude toward the course instructor (i.e., good/bad, worthless/valuable, fair/unfair, negative/positive) and the likelihood of taking another course with the instructor (i.e., likely/unlikely, impossible/possible, probable/improbable, would not/would). Affect toward the course content was measured by two, four-item subscales that asked about the student's attitude toward the course content (i.e., good/bad, worthless/valuable, fair/unfair, negative/positive) and the likelihood of enrolling in another course with similar content (likely/unlikely, impossible/possible, probable/ improbable, would not/would). Previous reliability coefficients ranging from .84 to .98 have been reported for the subscales (McCroskey, 1994; Myers \& Knox, 1999; Teven \& McCroskey, 1997). In this study, subscale scores were: affect toward the course content $(M=23.21, S D=4.62$, alpha $=$ 
$.89)$, affect toward the instructor $(M=24.0, S D=4.67$, alpha $=.90)$, likelihood of enrolling in another class with similar content $(M=21.43, S D=6.53$, alpha $=.95)$, and likelihood of taking another course with the instructor $(M=23.62, S D=6.39$, alpha $=.96)$.

\section{Data Analysis}

The hypothesis was explored using a series of Pearson Product-Moment correlations. LO and GO served alternately as the dependent variables and instructors' self-disclosure (i.e., amount, valence, depth), humor orientation, and narrative served alternately as the independent variables.

Research question one was answered using $2 \times 2$ analyses of variance (ANOVA). The ANOVA compared the mean scores of high LO/high GO, high LO/low GO, low LO/high GO and low LO/low GO to see if they are significantly different. A median split was performed to differentiate among high LO/high GO (60 students), high LO/low GO (46 students), low LO/high GO (39 students) and low LO/low GO (41 students). Instructors' self-disclosure (i.e., amount, valence, depth), humor, and narrative served alternately as the independent variables and the four categories of students' LO/GO served as the dependent variable.

Research question two was answered using a series of partial correlations. LO and GO were controlled for and the instructors' self-disclosure (i.e., amount, valence, depth), humor orientation, and narrative were correlated with the four subscales of the IAAI. 


\section{CHAPTER 3}

Results

Before the results were computed, a series of Pearson Product Moment correlations were calculated among instructors' message variables, LO, GO, and affective learning. Table 2 contains this matrix.

The first hypothesis predicted that perceived instructors' self-disclosure (i.e., amount, valence, depth), humor orientation, and narrative would be positively correlated with students' LO, but negatively correlated with students' GO. The hypothesis was not supported (see Table 1). Results of a series of Pearson Product-Moment correlations indicated that there were no significant relationships between students' LO and instructors' perceived amount of selfdisclosure $(r=-.01, p>.05)$, valence of self-disclosure $(r=.08, p>.05)$, depth of selfdisclosure $(r=.12, p>.05)$, humor orientation $(r=.00, p>.05)$, and narrative $(r=.05, p>.05)$. In addition, there were no significant relationships between students' GO and perceived instructors' amount of self-disclosure $(r=.01, p>.05)$, valence of self-disclosure $(r=-.05, p>$ $.05)$, depth of self-disclosure $(r=.12, p>.05)$, humor orient ation $(r=.08, p>.05)$, and narrative $(r=.10, p>.05)$

The first research question asked how students who varied in their LO/GO orientations differ in their assessment of instructors' self-disclosure (i.e., amount, balance, depth), humor orientation, and narrative. Results of an analysis of variance (ANOVA) indicated that there were no significant difference among the four categories of LO/GO and instructors' perceived amount of self-disclosure $[(\mathrm{F}(182)=.85, p>.05)]$, valence of self-disclosure $[(\mathrm{F}(182)=.24, p>.05)]$, depth of self-disclosure $[(\mathrm{F}(183)=.05, p>.05)]$, humor orientation $[(\mathrm{F}(183)=1.16, p>.05)]$, and narrative $[(\mathrm{F}(182)=.79, p>.05)]($ see Table 2$)$. 
The second research question asked how students' LO/GO affected the relationships among perceived instructors' self-disclosure (i.e., amount, valence, depth), humor orientation, and narrative and students' affect for course and affect for instructor. It was found that there were few significant relationships when LO/GO was controlled for (see Table 3). Results of partial correlation analysis indicated that when LO/GO was controlled for, the following series of correlations was obtained for self-disclosure: amount of self-disclosure and attitude toward course $(r=-.02, p>.05)$, amount and attitude toward instructor $(r=.10, p>.05)$, amount of self-disclosure and taking another course $(r=.15, p<.05)$, amount of self-disclosure and taking the instructor $(r=-.02, p>.08)$, valence of self-disclosure and attitude toward course $(r=.08, p$ $>.05)$, valence of self-disclosure and attitude toward instructor $(r=.14, p<.05)$, valence of selfdisclosure and taking another course $(r=.07, p>.05)$, valence of self-disclosure and taking the instructor $(r=.17, p<.05)$, depth of self-disclosure and attitude toward course $(r=.04, p>.05)$, depth of self-disclosure and attitude toward instructor $(r=.09, p>.05)$, depth of self-disclosure and taking another course $(r=.2, p<.05)$, and depth of self-disclosure and taking the instructor $(r=.07, p>.05)$

Results of partial correlation analysis indicated that when LO/GO was controlled for, the following series of correlations was obtained for humor orientation: humor orientation and attitude toward course $(r=.28, p<.05)$, humor orientation and attitude toward instructor $(r=$ $.33, p<.05)$, humor orientation and taking another course $(r=.31, p<.05)$, and humor orientation and taking the instructor $(r=.34, p<.05)$,

Results of partial correlation analysis indicated that when LO/GO was controlled for, the following series of correlations was obtained for narrative: narrative and attitude toward course $(r=.06, p>.05)$, narrative and attitude toward instructor $(r=.06, p>.05)$, narrative and taking 
another course $(r=.13, p<.05)$, and narrative and taking the instructor $(r=.09, p>.05)$.

Post-hoc analyses

Several post-hoc analyses were conducted to provide supplementary results. The first post-hoc analysis examined whether a significant relationship exists between LO and GO.

Results of a Pearson Product-Moment correlation indicated that there was a slight,significant relationship between $\mathrm{LO}$ and $\mathrm{GO}(r=.23, p<.05)$.

The second analysis examined whether a significant relationship exists between LO and affective learning. Results of a series of Pearson Product-Moment correlations indicated that there was no significant relationship between students' LO and attitude toward the course $(r=$ $.07, p>.05), \mathrm{LO}$ and attitude toward instructor $(r=.01, p>.05), \mathrm{LO}$ and taking another course $(r=.02, p>.05)$, and LO and taking the instructor $(r=.03, p>.05)$.

The third analysis examined whether a significant relationship exists between GO and affective learning. Results of a series of Pearson Product-Moment correlations indicated that one significant relationship exist between students' GO and attitude toward the course $(r=-.15, p<$ $.05)$. The remaining correlations between students' GO and attitude toward instructor $(r=-.07, p$ $>.05), \mathrm{GO}$ and taking another course $(r=-.07, p>.05)$, and GO and taking the instructor $(r=-$ $.03, p>.05)$ were not significant. 


\section{CHAPTER 4}

\section{Discussion}

The purpose of this study was to explore the relationship among instructors' message variables (i.e., self-disclosure, humor, narrative) and students' LO/GO and affective learning, of the three message variables, humor orientation was the only message variable that produced significant findings within the study.

Positive correlations were found between $\mathrm{HO}$ and affect for the course, $\mathrm{HO}$ and affect for the instructor, $\mathrm{HO}$ and affect for taking another course, and $\mathrm{HO}$ and affect for taking the instructor. Wanzer and Frymier (1999) obtained similar results, using Gorham's affective learning scale (1988), because instructors use humor to help students retain information (Kaplan \& Pascoe, 1977), clarify course content (Downs et al., 1988), and increase learning (Gorham \& Christophel, 1990; Hauck \& Thomas, 1972), instructors' humor may make the learning process more enjoyable, which results in increased affective le arning. Even when LO and GO were controlled for all four affective learning dimensions were positively correlated with HO. Specifically, positive correlations were found between $\mathrm{HO}$ and affect for the course, $\mathrm{HO}$ and affect for the instructor, $\mathrm{HO}$ and affect for taking another course, and $\mathrm{HO}$ and affect for taking the instructor. In examining these findings, it may be that when instructors use humor to clarify content (Downs et al., 1988), it may become more interesting. If the content is interesting to students, they may enjoy the course. Instructors who use humor in the classroom are able to establish a supportive classroom climate (Darling \& Civikly, 1987; Stuart \& Rosenfeld, 1994), which may result in feeling comfortable with the instructor. If humor is used to help students increase their learning (Gorham \& Christophel, 1990; Hauck \& Thomas, 1972), students may also want to learn more about the content. If students are excited about their learning 
experiences, they may be more willing to take classes that they perceive as fun and interesting. Instructors use humor to gain students' attention in the classroom (Punyanunt, 2000). If instructors are able to keep students' attention, the student may want to take the instructor again because students perceive instructors who use humor as interesting and entertaining.

Other findings relevant to the study indicated there were no significant relationships among the three instructor message variables and students' LO and GO. Instructors' message variables may not be related to students' LO because these three instructor behaviors may not be associated with learning in the mind of the student. Frymier and Weser (2001) stated that because LO students focus on what can be learned from a task, they may find too much guidance to be restrictive or an insult to their intelligence. If instructors use too many self-disclosive (i.e., amount, valence, depth), humor orientation, and narrative behaviors in the classroom, LO students might perceive these message variables as either a distraction from their learning or irrelevant to their learning. Moreover, if an instructor frequently uses these message variables, LO students may simply not pay attention to the instructor; hence, the message variable would not have an effect on them, whether the effect was positive or negative.

GO students, however, are focused on their grades (Frymier \& Weser, 2001); therefore, how instructors communicate may not be relevant to these GO students. GO students can be very selective in their attention to feedback, ignoring any suggestions not related to evaluation (Gorham, 1999). GO students may also not believe that instructors' message behaviors are relevant to the course material. If instructors are self-disclosing, using humor, and using narrative, students may not believe the information is relevant to the course material or relevant to what will be on the next examination. Therefore, regardless of the instructors' communication behaviors, GO students may not pay attention to the message the instructor is trying to convey. 
It was found that there was no difference among high LO/high GO, high LO/low GO, low LO/high GO, and low LO/low GO of student orientations and instructors' message variables. This finding provides added support for the findings obtained within the first hypothesis. Even though instructors use self-disclosure, humor, and narratives to clarify content (Downs et al., 1988), students may not associate these behaviors with learning. Rather, students may focus on the content itself rather than the method used to convey the content. Consequently, course content is the most important factor and how the instructor teaches the content may not be important to students as long as they know what to do with the content.

When controlling for students' LO and GO, few significant relationships were obtained among self-disclosure, narrative, and affective learning. For the relationship between selfdisclosure and affective learning, four significant positive correlations were found. These four positive correlations are amount of self-disclosure and affect for taking the course, valence of self-disclosure and affect for the instructor, valence of self-disclosure and affect for taking the instructor, and depth of self-disclosure and affect for taking another course. In looking at the collective findings, it is possible if an instructor is able to self-disclose information that clarifies content of the subject (Downs et al., 1988), students may find the content of the course more interesting and be more willing to take another course dealing with the same subject matter. Instructors who self-disclose positive information may also have students who like them more and evaluate them more highly. Self-disclosure in the classroom also leads to students' perceived solidarity in their relationships with the instructors (Sorensen, 1989); therefore, when instructors self-disclose, students should like them more. Self-disclosure can bring individuals closer together (Altman \& Taylor, 1973), which may cause an increase in student affect for taking the instructor. Moreover, instructors who use self-disclosure in the classroom are perceived as being 
more effective (Nussbaum et al., 1985). Therefore, instructors' self-disclosure may lead to a student wanting to take the instructor again for another course.

Only one significant finding was obtained between narrative and affect learning, which was a positive correlation between narrative and affect for taking another course. When narratives are used in the classroom, students become more involved in the classroom (Kirkland \& Gold, 1983). This involvement may help students enjoy their classroom experience. Because narratives are beneficial for students to enjoy and understand the course content (Eble, 1976), students may want to take similar courses.

The results of this study have many implications for instructors and students. Even though the first hypothesis was not supported, this finding demonstrates that students may not associate instructors' message variables with learning. If students are able to associate instructors' communication behaviors with learning, they may have a more positive attitude toward the learning process. Instructors may want to focus on demonstrating to students that the learning process can be an enjoyable experience. Although students' attitudes toward learning may be either high LO/high GO, high LO/low GO, low LO/high GO or low LO/low GO, it was found that there were no difference among the four categories and instructors' message variables. Due to this lack of difference, students may see an instructor's primary role in the classroom as a facilitator of knowledge. Even though all three instructors' message variables are important in the classroom, this study indicates that instructors' humor orientation may be the most significant message variable. Instructors who are successful and feel comfortable using humor in the classroom should use humor appropriately in the classroom to increase students' affective learning.

A limitation of this study was that students reported their perceptions of a previous 
instructor's use of self-disclosure (i.e. amount, valence, depth), humor orientation, and narrative without supplying any other information about the instructor. The subject being taught might influence whether students view these message variables as appropriate to use in the course or as relevant to the course content. Another limitation is that many of the participants $(N=52)$ were high LO/ high GO. Because these students are concerned with both their grades and their learning, they may have not focused on how the instructor teaches, but what the instructor teaches.

Future researchers should consider conducting an experiment that manipulates instructors' use of self-disclosure (i.e. amount, valence, depth), humor orientation, and narrative to determine whether students (a) can identify when instructors use these behaviors and (b) perceive the message variables as being beneficial or irrelevant. In addition, future research should examine instructors' own learning orientation or grade orientation to influence how well LO/GO students perform in their course. By studying instructors' behaviors in the college classroom, researchers may be able to improve instructors' effectiveness in the classroom setting. In sum, the findings in the study suggest that instructors' message variables were not correlated with students' LO and GO, but instructors' message variables were positively correlated with some (or all) of the dimensions of affective learning. The findings in this study are important because LO and GO are two characteristics that affect students' perceptions of the importance of classroom content. By understanding these two characteristics, instructors may be able to focus on students' educational needs and teach in a manner beneficial for both LO and GO students. 


\section{References}

Alexitch, L. R. (1997). Students' educational orientation and preferences for advising from university professors. Journal of College Student Development, 38, 333-342.

Alexitch, L. R., \& Page, S. (2001). Educational orientation and students' perceptions of a university education. Guidance \& Counseling, 17, 8-16.

Altman, I., \& Taylor, D. A. (1973). Social penetration: The development of interpersonal relationships. New York: Holt, Rinehart, \& Winston.

Beck, H. P., Rorrer-Woody, S., \& Pierce, L. G. (1991). The relations of learning and grade orientations to academic performance. Teaching of Psychology, 18, 35-37.

Bethea, L. S. (2001). The function of humor within the lives of older adults. Communication Quarterly, 49, 49-59.

Bippus, A. M. (2000). Humor usage in comforting episodes: Factors predicting outcomes. Western Journal of Communication, 64, 359-384.

Booth-Butterfield, S., \& Booth-Butterfield, M. (1991). Individual differences in the communication of humorous messages. Southern Communication Journal, 56, 32-40.

Bograd, R., \& Spilka, B. (1996). Self-disclosure and marital satisfaction in mid-life and late-life remarriages. International Journal of Aging \& Human Development, 42, 161-172.

Bryant, J., Comisky, P. W., Crane, J. S., \& Zillmann, D. (1980). Relationship between college teachers' use of humor in the classroom and students' evaluations of their teachers. Journal of Educational Psychology, 72, 511-519.

Bryant, J., Comisky, P., \& Zillmann D. (1979). Teachers' humor in the college classroom. Communication Education, 28, 110-118.

Campbell, K. L., Martin, M. M., \& Wanzer, M. B. (2001). Employee perceptions of manager 
humor orientation, assertiveness, responsiveness, approach/avoidance strategies, and satisfaction. Communication Research Reports, 18, 67-74.

Cayanus, J. L., \& Martin, M. M. (2002, November). Development of a teacher self-disclosure scale. Paper presented at the annual meeting of the National Communication Association, New Orleans, LA.

Civikly, J. M. (1986). Humor and the enjoyment of college teaching. New Directions for Teaching and Learning, 26, 61-70.

Collins, N. L., \& Miller, L. C. (1994). Self-disclosure and liking: A meta-analytic review. Psychological Bulletin, 116, 457-475.

Cozby, P. C. (1973). Self-disclosure: A literature review. Psychological Bulletin, 79, 73-91.

Darling, A. L., \& Civikly, J. M. (1987). The effect of teacher humor on student perceptions of classroom communicative climate. Journal of Classroom Interaction, 22, 24-30.

Dindia, K., \& Allen, M. (1992). Sex differences in self-disclosure: A meta-analysis. Psychological Bulletin, 112, 106-124.

Dolin, D. J. (1995). An alternative form of teacher affinity-seeking measurement. Communication Research Reports, 12, 220-226.

Downs, V. C., Javidi, M., \& Nussbaum, J. F. (1988). An analysis of teachers' verbal communication within the college classroom: Use of humor, self-disclosure, and narratives. Communication Education, 37, 127-141.

Eble, K. E. (1976). The craft of teaching. San Francisco: Jossey-Bass.

Eison, J., \& Pollio, H. R. (1985). A multidimensional approach to the definition of college students' learning styles. Journal of College Student Personnel, 26, 434-443.

Frymier, A. B. (1994). The use of affinity-seeking in producing liking and learning in the 
classroom. Journal of Applied Communication Research, 22, 87-105.

Frymier, A. B., \& Weser, B. (2001). The role of student predispositions on student expectations for instructor communication behavior. Communication Education, 50, 314-326.

Gilbert, S. J., \& Whiteneck, G. G. (1976). Toward a multidimensional approach to the study of self disclosure. Human Communication Research, 2, 347-355.

Goldstein, G. S., \& Benassi, V. A. (1994). The relation between teacher self-disclosure and student classroom participation. Teaching of Psychology, 21, 212-216.

Gorham, J. (1999). Diversity in the classroom dynamics. In J. A. Daly, G. Friedrich, \& A. Vangelisti (Eds.), Teaching communication: Theory, research, and methods $\left(2^{\text {nd }}\right.$ ed.) (pp. 257-268). Mahwah, NJ: Lawrence Erlbaum.

Gorham, J., \& Christophel, D. M. (1990). The relationship of teachers' use of humor in the classroom to immediacy and student learning. Communication Education, 39, 46-63.

Graham, E. E. (1995). The involvement of sense of humor in the development of social relationships. Communication Reports, 8, 158-167.

Graham, E. E., Papa, M. J., \& Brooks, G. P. (1992). Functions of humor in conversations: Concepts and measurement. Western Journal of Communication, 56, 161-183.

Hauck, W. E., \& Thomas, J. W. (1972). The relationship of humor to intelligence, creativity, and intentional and incidental learning. The Journal of Experimental Education, 40, 52-55.

Hampes, W. P. (2001). Relation between humor and empathic concern. Psychological Reports, $88,241-244$.

Holladay, S. J. (1987, November). Narrative activity and teacher effectiveness: An investigation of story-telling in the classroom. Paper presented at the annual meeting of the Speech Communication Association, Boston, MA. 
Javidi, M. N., \& Long, L. W. (1989). Teachers' use of humor, self-disclosure, and narrative activity as a function of experience. Communication Research Reports, 6, 47-52.

Johnson, B. G., \& Beck, H. P. (1988). Strict and lenient grading scales: How do they affect the performance of college students with high and low SAT scores? Teaching of Psychology, $15,127-131$.

Kaplan, R. M., \& Pascoe, G. C. (1977). Humorous lectures and humorous examples: Some effects upon comprehension and retention. Educational Psychology, 69, 61-65.

Kauffmann, D. R., Chupp, B., Hershberger, K., Martin, L., \& Eastman, K. (1987). Learning vs grade orientation: Academic achievement, self-reported orientation, and personality variables. Psychological Reports, 60, 145-146.

Kirkwood, W. G., \& Gold, J. (1983). Using teaching stories to explore philosophical themes in the classroom. Metaphilosophy, 14, 341-352.

Kuiper, N. A., \& Martin, R. A. (1993). Humor and self-concept. Humor, 6, 251-270.

Lawrence, K. R., \& Frymier, A. B. (2002, November). The relationship of student-centered and instructor-centered teaching with learning and grade orientation. Paper presented at the annual meeting of the National Communication Association, New Orleans, LA.

Martin, R. A., \& Lefcourt, H. M. (1983). Sense of humor as a moderator of the relation between stressors and moods. Journal of Personality and Social Psychology, 45, 1313-1324.

McCroskey, J. C. (1994). Assessment of affect toward communication and affect toward instruction in communication. In S. Morreale \& M. Brooks (Eds.), Assessing college student competency in speech communication (pp. 56-71). Annandale, VA: Speech Communication Association.

Milton, O., Pollio, H. R., \& Eison, J. A. (1986). Making sense of college grades. San Francisco: 
Jossey-Bass.

Murstein, B. I., \& Brust, R. G. (1985). Humor and interpersonal attraction. Journal of Personality Assessment, 49, 637-640.

Myers, S. A., \& Knox, R. L. (1999). Verbal aggression in the college classroom: Perceived instructor use and student affective learning. Communication Quarterly, 47, 33-45.

Neuliep, J. W. (1991). An examination of the content of high school teachers' humor in the classroom and the development of an inductively derived taxonomy of classroom humor. Communication Education, 40, 343-355.

Nussbaum, J. F., Comadena, M. E., \& Holladay, S. J. (1985, May). Verbal and nonverbal behaviors of highly effective teachers. Paper presented at the annual meeting of the International Communication Association, Honolulu, HI.

Nussbaum, J. F., \& Scott, M. D. (1979). Instructor communication behaviors and their relationship to classroom learning. In D. Nimmo (Ed.), Communication yearbook 4 (pp. 533-552). New Brunswick, NJ: Transaction.

Pearce, W. B., \& Sharp, S. M. (1973). Self-disclosing communication. Journal of Communication, 23, 409-425.

Plax, T. G., Kearney, P., McCroskey, J. C., \& Richmond, V. P. (1986). Power in the classroom VI: Verbal control strategies, nonverbal immediacy, and affective learning. Communication Education, 39, 181-184.

Pollio, H. R., \& Beck, H. P. (2000). Perceptions of learning and grade orientation in, and by, contemporary college students and faculty. The Journal of Higher Education, 71, 84-102.

Punyanunt, N. M. (2000). The effects of humor on perceptions of compliance-gaining in the college classroom. Communication Research Reports, 17, 30-38. 
Richardson, T. R., Kring, J. P., \& Davis, S. F. (1997). Student characteristics of learning or grade orientation influence preferred teaching style. College Student Journal, 31, 347-351.

Rizzo, B. J., Booth-Butterfield, M., \& Wanzer, M. B. (1999). Individual differences in managers' use of humor: Subordinate perceptions of managers' humor. Communication Research Reports, 16, 360-369.

Robinson, R. Y. (1993). The usefulness of the verbal receptivity measure in instructional communication research. Communication Quarterly, 41, 292-298.

Sallinen-Kuparinen, A. (1992). Teacher communicator style. Communication Education, 41, $153-166$.

Sanders, J. A., \& Wiseman, R. L. (1990). The effects of verbal and nonverbal teacher immediacy on perceived cognitive, affective, and behavioral learning in the multicultural classroom. Communication Education, 39, 341-353.

Scott, M. D., \& Nussbaum, J. F. (1981). Student perceptions of instructor communication behaviors and their relationship to student evaluation. Communication Education, 30, 4453.

Sidelinger, R. J., \& McCroskey, J. C. (1997). Communication correlates of teacher clarity in the college classroom. Communication Research Reports, 14, 1-10.

Sorensen, G. (1989). The relationships among teachers' self-disclosive statements, students' perceptions, and affective learning. Communication Education, 38, 259-276.

Stacks, D. W., \& Stone, J. D. (1984). An examination of the effect of basic speech courses, selfconcepts, and self-disclosure on communication apprehension. Communication Education, 33, 317-331.

Stuart, W. D., \& Rosenfeld, L. B. (1994). Students' perceptions of teacher humor and classroom 
climate. Communication Research Reports, 11, 87-97.

Teven, J. J., \& McCroskey, J. C. (1997). The relationship of perceived teacher caring with student learning and teacher evaluation. Communication Education, 46, 1-9.

Wanzer, M. B., Booth-Butterfield, M., \& Booth-Butterfield, S. (1995). The funny people: A source orientation to the communication of humor. Communication Quarterly, 43, 142154.

Wanzer, M. B., Booth-Butterfield, M., \& Booth-Butterfield, S. (1996). Are funny people popular? An exa mination of humor orientation, loneliness and social attraction. Communication Quarterly 44, 42-52.

Wanzer, M. B., Booth-Butterfield, M., \& Booth-Butterfield, S. (1997, November). “If we didn’t use humor, we'd cry:" Predispositional and situational influences on humorous coping communication in health care settings. Paper presented at the annual meeting of the National Communication Association, Chicago, IL.

Wanzer, M. B., \& Frymier, A. B. (1999). The relationship between student perceptions of instructor humor and student's reports of learning. Communication Education, 48, 48-62.

Wheeless, L. R. (1978). A follow-up study of the relationships among trust, disclosure, and interpersonal solidarity. Human Communication Research, 4, 143-157.

Wheeless, L. R., \& Grotz, J. (1976). Conceptualization and measurement of reported selfdisclosure. Human Communication Research, 2, 338-346.

Wheeless, L. R., \& Grotz, J. (1977). The measure of trust and its relationship to selfdisclosure. Human Communication Research, 3, 250-257.

Wheeless, L. R., Nesser, K., \& McCroskey, J. C. (1986). The relationship of self-disclosure and disclosiveness to high and low communication apprehension. Communication Research 
Reports, 3, 129-134.

Witt, P. L., \& Wheeless, L. R. (2001). An experimental study of teachers' verbal and nonverbal immediacy and students' affective and cognitive learning. Communication Education, 50, 327-342.

Wrench, J. S., \& McCroskey, J. C. (2001). A temperamental understanding of humor communication and exhilaratability. Communication Quarterly, 49, 35-52.

Young, S. L., \& Bippus, A. M. (2001). Does it make a difference if they hurt you in a funny way? Humorous and non-humorously phrased hurtful messages in personal relationships. Communication Quarterly, 49, 35-52.

Yovitch, N. A., Dale, J. A., \& Hudak, M. A. (1990). Benefits of humor in reduction of threatinducted anxiety. Psychological Reports, 66, 51-58. 
Appendix A:

Revised Self-Disclosure scale (Wheeless, 1978)

Complete the following questions in reference to your PREVIOUS instructor. Identify this instructor by his or her initials.

Record your impressions of the way the instructor that you just identified communicates while teaching. For each statement, supply the appropriate number in the space provided. None of the statements has a right or wrong answer.

If you strongly agree with the statement, supply a 7.

If you agree with the statement, supply a 6.

If you moderately agree with the statement, supply a $\mathbf{5}$.

If you are undecided with the statement, supply a 4.

If you moderately disagree with the statement, supply a $\mathbf{3}$.

If you disagree with the statement, supply a 2.

If you strongly disagree with the statement, supply a $\mathbf{1 .}$

1. When my instructor wishes, his/her self-disclosures are always accurate reflections of who he/she really is.

2. My instructor does not often talk about himself/herself.

3. My instructor usually discloses positive things about himself/herself.

4. My instructor intimately discloses who he/she really is, openly and fully in his/her conversation.

5. My instructor cannot reveal himself/herself when he/she wants to because he/she does not know himself/herself thoroughly enough.

6. My instructor's statements of his/her feeling are usually brief.

7. On the whole, my instructor disclosures about himself/herself are more negative than positive.

8. Once my instructor gets started, his/her self-disclosures last a long time.

9. My instructor is often not confident that his/her expressions of his/her own feelings, emotions, and experiences are true reflections of himself/herself.

10. When my instructor expresses his/her personal feelings, he/she are always aware of what he/she are doing and saying.

11. My instructor normally reveals "bad" feelings he/she has about himself/herself.

12. My instructor often discloses intimate, personal things about himself/herself without hesitation.

13. My instructor always feels completely sincere when he/she reveal his/her own feelings and experiences.

14. When my instructor reveals his/her feeling about himself/herself, he/she consciously intends to do so.

15. My instructor usually talks about himself/herself for fairly long periods at a time.

16. My instructor normally "expresses" his/her good feelings about himself/herself.

17. I feel that my instructor sometimes does NOT control his/her self-disclosures of personal or intimate things he/she tell about himself/herself. 
18. My instructor's self-disclosures are completely accurate reflections of who he/she really is.

19. My instructor often talks about himself/herself.

20. My instructor often reveals more undesirable things about himself/herself than desirable things.

21. My instructor is not always honest in his/her self-disclosures.

22. When my instructor is self-disclosing, he/she is consciously aware of what he/she is revealing.

23. My instructor's conversation lasts the least time when he/she is discussing himself/herself.

24. My instructor's statements about his/her feelings, emotions, and experiences are always accurate self-perceptions.

25. Once my instructor gets started, he/she intimately and fully reveal himself/herself in his/her self disclosures.

26. My instructor usually discloses negative things about himself/herself.

27. My instructor often discusses his/her feelings about himself/herself.

28. My instructor is always honest in his/her self-disclosures.

29. Only infrequently does my instructor express his/her personal beliefs and opinions.

30. On the whole, my instructor's disclosures about himself/herself are more positive than negative.

31. My instructor does not always feel completely sincere when he/she reveal own feelings, emotions, behaviors, or experience. 
Appendix B:

Humor Orientation scale (Booth-Butterfield \& Booth-Butterfield, 1991)

Complete the following questions in reference to your PREVIOUS instructor. Identify this instructor by his or her initials.

Record your impressions of the way the instructor that you just identified communicates while teaching. For each statement, supply the appropriate number in the space provided. None of the statements has a right or wrong answer.

If you strongly agree with the statement, supply a $\mathbf{5}$.

If you agree with the statement, supply a 4.

If you neither agree nor disagree with the statement, supply a 3.

If you disagree with the statement, supply a 2.

If you strongly disagree with the statement, supply a $\mathbf{1 .}$

1. My instructor regularly tells jokes and funny stories when he/she is around students.

2. Students usually laugh when my instructor tells a joke or story.

3. My instructor has no memory for jokes or funny stories.

4. My instructor can be funny without having to rehearse a joke.

5. Being funny is a natural communication style with my instructor.

6. My instructor cannot tell a joke well.

7. My instructor is seldom asked to tell stories.

8. I would say that my instructor is a funny person.

9. People do not seem to pay close attention when my instructor tells a joke.

10. Even funny jokes seem flat when my instructor tells them.

11. My instructor can easily remember jokes and stories.

12. People often ask my instructor to tell jokes and stories.

13. I would not say that my instructor is a funny person.

14. My instructor does not tell jokes or stories, even when asked to.

15. My instructor tells stories and jokes very well.

16. Of all the people I know, my instructor is one of the funniest.

17. My instructor uses humor to communicate in a variety of situations. 


\section{Appendix C:}

\section{Narrative Measure}

Complete the following questions in reference to your PREVIOUS instructor. Identify this instructor by his or her initials.

Record your impressions of the way the instructor that you just identified communicates while teaching. For each statement, supply the appropriate number in the space provided. None of the statements has a right or wrong answer.

If you strongly agree with the statement, supply a $\mathbf{5}$.

If you agree with the statement, supply a 4.

If you neither agree nor disagree with the statement, supply a $\mathbf{3}$.

If you disagree with the statement, supply a 2 .

If you strongly disagree with the statement, supply a $\mathbf{1 .}$

1. My instructor never tells stories in class.

2. My instructor is a good storyteller.

3. My instructor relates class materials to stories in his/her life.

4. My instructor tells factual stories.

5. My instructor tells fictional stories.

6. My instructor tells stories about his/her personal life.

7. When my instructor tells stories, he/she is the main character.

8. My instructor tells stories that result in greater class discussion.

9. My instructor tells stories that are irrelevant to course material.

10. When my instructor tells stories, he/she uses students as the main character. 


\section{Appendix D:}

\section{LOGO II scale (Milton et al., 1986)}

Below is a series of statements taken from interviews with a large number of college students concerning their reactions to various courses, instructors, and classroom policies. Please read each statement carefully and indicate how strongly you agree or disagree with each item.

If you strongly agree with the statement, supply a $\mathbf{5}$.

If you agree with the statement, supply a 4.

If you neither agree nor disagree with the statement, supply a $\mathbf{3}$.

If you disagree with the statement, supply a 2 .

If you strongly disagree with the statement, supply a $\mathbf{1 .}$

1. I enjoy classes in which the instructor attempts to relate material to concerns beyond the classroom.

2. I think it is unfair to test students on material not covered in class lectures and discussions, even if it is in reading assignments.

3. I dislike courses which require ungraded out-of-class activities.

4. I prefer to write a term paper on interesting material rather than take a test on the same general topic.

5. I get annoyed when lectures or class presentations are only rehashes of easy reading assignments.

6. Written assignments (such as homework, projects, and so on) that are not graded are a waste of my time.

7. I appreciate an instructor who provides honest and detailed evaluations of my work, although such evaluation is sometimes unpleasant.

8. I think that without regularly scheduled exams, I would not learn and remember very much.

9. Instructors expect too much out-of-class reading and study by students.

10. I find the process of learning new material fun.

11. I dislike courses in which a lot of material is presented in class, or in readings, that does not appear on exams.

12. Easy classes that are not pertinent to my educational goals generally bore me.

13. A teacher's comments on an essay test mean more to me than my actual test score.

14. I do not find studying at home to be interesting or pleasant.

15. I am more concerned about seeing which questions I missed than I am with finding out my test grade.

16. I think grades provide me with a good goal to work toward. 


\section{Appendix E:}

Instructional Affect Assessment Instrument (McCroskey, 1994)

Using the scales, please evaluate this class. For each statement, circle the appropriate number which best represents your feelings. None of the statements has a right or wrong answer.

My attitude about the content in this class is:

\begin{tabular}{|c|c|c|c|c|c|c|c|c|}
\hline 1. Good & 1 & 2 & 3 & 4 & 5 & 6 & 7 & $\mathrm{Bad}$ \\
\hline 2. Worthless & 1 & 2 & 3 & 4 & 5 & 6 & 7 & Valuable \\
\hline 3. Fair & 1 & 2 & 3 & 4 & 5 & 6 & 7 & Unfair \\
\hline 4. Negative & 1 & 2 & 3 & 4 & 5 & 6 & 7 & Positive \\
\hline
\end{tabular}

My attitude about the instructor in this class is:

\begin{tabular}{|c|c|c|c|c|c|c|c|c|}
\hline 1. Good & 1 & 2 & 3 & 4 & 5 & 6 & 7 & $\mathrm{Bad}$ \\
\hline 2. Worthless & 1 & 2 & 3 & 4 & 5 & 6 & 7 & Valuable \\
\hline 3. Fair & 1 & 2 & 3 & 4 & 5 & 6 & 7 & Unfair \\
\hline 4. Negative & 1 & 2 & 3 & 4 & 5 & 6 & 7 & Positive \\
\hline
\end{tabular}

My likelihood of actually enrolling in another class with similar content, if I had the choice and if my schedule permitted: (If you are graduating, assume you would still be here.)

\begin{tabular}{|c|c|c|c|c|c|c|c|c|}
\hline 1. Likely & 1 & 2 & 3 & 4 & 5 & 6 & 7 & Unlikely \\
\hline 2. Impossible & 1 & 2 & 3 & 4 & 5 & 6 & 7 & Possible \\
\hline 3. Probable & 1 & 2 & 3 & 4 & 5 & 6 & 7 & Improbable \\
\hline 4. Would not & 1 & 2 & 3 & 4 & 5 & 6 & 7 & Would \\
\hline
\end{tabular}

The likelihood of my taking another course with this teacher, if I had a choice, is: (If you are graduating, assume you would still be here.)

\begin{tabular}{|c|c|c|c|c|c|c|c|c|}
\hline 1. Likely & 1 & 2 & 3 & 4 & 5 & 6 & 7 & Unlikely \\
\hline 2. Impossible & 1 & 2 & 3 & 4 & 5 & 6 & 7 & Possible \\
\hline 3. Probable & 1 & 2 & 3 & 4 & 5 & 6 & 7 & Improbable \\
\hline 4. Would not & 1 & 2 & 3 & 4 & 5 & 6 & 7 & Would \\
\hline
\end{tabular}


TABLE 1

Scales, Means, Standard Deviations, and Reliabilities.

\begin{tabular}{|c|c|c|c|}
\hline Scale & Mean & Standard Deviation & Reliability \\
\hline $\begin{array}{l}\text { Amount of self- } \\
\text { disclosure }\end{array}$ & 28.10 & 7.75 & .79 \\
\hline $\begin{array}{l}\text { Valence of self- } \\
\text { disclosure }\end{array}$ & 35.31 & 6.46 & .77 \\
\hline $\begin{array}{l}\text { Depth of self- } \\
\text { disclosure }\end{array}$ & 16.75 & 5.79 & .73 \\
\hline $\begin{array}{l}\text { Humor } \\
\text { Orientation }\end{array}$ & 62.18 & 15.20 & .95 \\
\hline Narrative & 34.50 & 7.09 & .80 \\
\hline Learning Orientation & 27.38 & 4.62 & .66 \\
\hline Grade Orientation & 28.36 & 4.69 & .60 \\
\hline $\begin{array}{l}\text { Attitude toward } \\
\text { course content }\end{array}$ & 23.21 & 4.62 & .89 \\
\hline $\begin{array}{l}\text { Attitude toward the } \\
\text { instructor }\end{array}$ & 24.00 & 4.67 & .90 \\
\hline $\begin{array}{l}\text { Taking another class } \\
\text { with similar content }\end{array}$ & 21.43 & 6.53 & .95 \\
\hline $\begin{array}{l}\text { Taking another course } \\
\text { with the instructor }\end{array}$ & 23.62 & 6.39 & .96 \\
\hline
\end{tabular}


TABLE 2

Correlation Matrix Among All Variables

\begin{tabular}{|c|c|c|c|c|c|c|c|c|c|c|c|}
\hline & 1. & 2. & 3. & 4. & 5. & 6. & 7. & 8. & 9. & 10. & 11. \\
\hline $\begin{array}{l}\text { 1. Amount of } \\
\text { self- } \\
\text { disclosure }\end{array}$ & & $.23^{*}$ & $.62^{*}$ & $.21 *$ & $.27 *$ & -.01 & .01 & -.01 & .10 & $.15^{*}$ & .08 \\
\hline $\begin{array}{l}\text { 2. Valence of } \\
\text { self- } \\
\text { disclosure }\end{array}$ & $.23 *$ & & -.13 & $.25^{*}$ & $.18^{*}$ & .08 & -.05 & .10 & .14 & .07 & $.17 *$ \\
\hline $\begin{array}{l}\text { 3. Depth of } \\
\text { self- } \\
\text { disclosure }\end{array}$ & $.62 *$ & -.13 & & $.16^{*}$ & $.19 *$ & .12 & .12 & .04 & .09 & $.20 *$ & .07 \\
\hline $\begin{array}{l}\text { 4. Humor } \\
\text { Orientation }\end{array}$ & $.21 *$ & $.25^{*}$ & $.16^{*}$ & & $.03^{*}$ & .00 & .08 & $.27 *$ & $.33 *$ & $.33 *$ & $.36^{*}$ \\
\hline 5. Narrative & $.27 *$ & $.18^{*}$ & $.19 *$ & $.03 *$ & & .05 & .08 & .06 & .07 & $.16^{*}$ & .12 \\
\hline $\begin{array}{l}\text { 6. Learning } \\
\text { Orientation }\end{array}$ & -.01 & .08 & .12 & .00 & .05 & & $.23 *$ & .07 & .01 & .02 & .03 \\
\hline $\begin{array}{l}\text { 7. Grade } \\
\text { Orientation }\end{array}$ & .01 & -.05 & .12 & .08 & .10 & .23 & & $-.15^{*}$ & -.07 & -.07 & -.03 \\
\hline $\begin{array}{l}\text { 8. Attitude } \\
\text { course }\end{array}$ & -.01 & .10 & .04 & $.27 *$ & .06 & .07 & $-.15^{*}$ & & $.75^{*}$ & $.62 *$ & $.72 *$ \\
\hline $\begin{array}{l}\text { 9. Attitude } \\
\text { instructor }\end{array}$ & .10 & .14 & .09 & $.33^{*}$ & .07 & .01 & -.07 & $.75^{*}$ & & $.49 *$ & $.78 *$ \\
\hline $\begin{array}{l}\text { 10. Taking } \\
\text { class }\end{array}$ & $.15^{*}$ & .07 & $.20 *$ & $.33^{*}$ & $.16^{*}$ & .02 & -.07 & $.62 *$ & $.49^{*}$ & & $.58 *$ \\
\hline $\begin{array}{l}\text { 11. Taking } \\
\text { instructor }\end{array}$ & .08 & $.17^{*}$ & .07 & $.36^{*}$ & .12 & .03 & -.03 & $.72 *$ & $.78 *$ & $.58 *$ & \\
\hline
\end{tabular}


Table 3

Pearson-Product Moment Correlations between Instructors' Message Variables and LO/GO

\begin{tabular}{lcc}
\hline \multicolumn{1}{c}{ Message Variables } & LO & GO \\
\hline Amount of self-disclosure & -.01 & .01 \\
Valence of self-disclosure & .08 & -.05 \\
Depth of self-disclosure & .12 & .12 \\
Humor orientation & .00 & .08 \\
Narrative & .05 & .10 \\
\hline
\end{tabular}

Note. All correlations are non significant. 
Table 4

Differences in Mean Scores Among LO/GO

\begin{tabular}{lcccccc}
\hline \multicolumn{1}{c}{$\begin{array}{c}\text { Message } \\
\text { Variables }\end{array}$} & 1 & 2 & 3 & 4 & $\mathrm{~F}$ & $\mathrm{P}$ \\
\hline $\begin{array}{l}\text { Amount of } \\
\text { self- } \\
\text { disclosure }\end{array}$ & 27.88 & 27.19 & 28.62 & 28.25 & .85 & .85 \\
$\begin{array}{l}\text { Valence of } \\
\text { self- } \\
\text { disclosure }\end{array}$ & 34.95 & 35.12 & 36.00 & 35.02 & .24 & .87 \\
$\begin{array}{l}\text { Depth of } \\
\text { self- } \\
\text { disclosure }\end{array}$ & 16.72 & 16.72 & 16.38 & 16.85 & .05 & .99 \\
$\begin{array}{l}\text { Humor } \\
\text { orientation }\end{array}$ & 62.26 & 59.37 & 65.36 & 62.73 & 1.16 & .33 \\
Narrative & 35.10 & 33.17 & 34.59 & 35.10 & .79 & .50 \\
\hline
\end{tabular}

Note. 1= High LO/High GO, 2= High LO/Low GO 3= Low LO/High GO 4= Low LO/Low GO. All $\mathrm{F}$ values are nonsignificant 
Table 5

Partial Correlations between Instructors' Message Variables and Affective Learning Controlling for $L O / G O$

\begin{tabular}{lcccc}
\hline \multicolumn{1}{c}{$\begin{array}{c}\text { Message } \\
\text { Variables }\end{array}$} & $\begin{array}{c}\text { Affect for } \\
\text { course }\end{array}$ & $\begin{array}{c}\text { Affect for } \\
\text { instructor }\end{array}$ & $\begin{array}{c}\text { Taking } \\
\text { course }\end{array}$ & $\begin{array}{c}\text { Taking } \\
\text { instructor }\end{array}$ \\
\hline $\begin{array}{l}\text { Amount of } \\
\text { self-disclosure }\end{array}$ & -.02 & .10 & $.15^{*}$ & .08 \\
$\begin{array}{l}\text { Valence of } \\
\text { self-disclosure }\end{array}$ & .08 & $.14^{*}$ & .07 & $.17^{*}$ \\
$\begin{array}{l}\text { Depth of self- } \\
\text { disclosure }\end{array}$ & .04 & .09 & $.20^{*}$ & .07 \\
$\begin{array}{l}\text { Humor } \\
\text { orientation }\end{array}$ & $.28^{*}$ & $.33^{*}$ & $.31^{*}$ & $.34^{*}$ \\
Narrative & .06 & .06 & & $.13^{*}$ \\
\end{tabular}

Note. ${ }^{*} \mathrm{p}<.01$ 